\title{
Immature stages of the moth Lobeza dentilinea (Lepidoptera: Notodontidae), with redescription of the species based on male and female morphology
}

\author{
Lívia R. Pinheiro',2; Renato O. Silva' \& Marcelo Duarte ${ }^{1,3}$ \\ ${ }^{1}$ Museu de Zoologia da Universidade de São Paulo. Avenida Nazaré 481, Ipiranga, 04263-000 São Paulo, SP, Brazil. \\ 2 Programa de Pós-graduação em Ciências Biológicas (Zoologia), Instituto de Biociências, Departamento de Zoologia, \\ Universidade de São Paulo. Rua do Matão, Travessa 14, 321, Butantã, 05508-900 São Paulo, SP, Brazil. \\ ${ }_{3}^{3}$ Corresponding author. E-mail: mduartes@usp.br
}

\begin{abstract}
Egg and pupa of Lobeza dentilinea Schaus, 1901 are described and illustrated for the first time. Eggs are smooth, dome-shaped, and greenish at oviposition. Last instar larvae have an aposematic coloration and the chaetotaxy is very similar to other notodontines, except for the number of lateral setae: L. dentilinea has three instead of four lateral setae on abdominal segments A3-A6. Pupae are light brown and typical of the family, with the last abdominal segments broadly round. Evidence from the adult morphology supporting the placement of the genus in Notodontinae includes proboscis smaller than the length of the head, epiphysis with more than half the length of tibia, tarsal claws simple, and labial palpi short. Male and female are confidently associated, and a redescription of the species is presented based on both sexes. Larvae of $L$. dentilinea are here recorded feeding on a Melastomataceae.
\end{abstract}

KEY WORDS. Cteniophore; genitalia; larva; Neotropical region; pupa.

Notodontidae comprises approximately 3,000 species and they occur mainly in the neotropics (SEITZ 1932). The larvae are generally brightly colored, and are peculiar among Lepidoptera for feeding on arboreous species rather than herbs or shrubs, as caterpillars usually do (STEHR 1987).

As virtually all groups of holometabolous insects, immature stages of Notodontidae are poorly known, especially those of Neotropical species (Miller 1992a, b). This lack of knowledge is particularly problematic given the recognized importance of larval and pupal characters to establish a reasonable classification, which is still uncertain for Notodontidae (Miller 1991, 1992a).

DYAR (1897) proposed the first classification of world notodontids based on adult and larval characters. Despite of being an important contribution, this work does not give emphasis to the Neotropical fauna. The current classification of Notodontidae is based on the works of Miller (1991, 1992a) and is supported to a great extent by larval, pupal and adult characters. According to this author, the family is divided into nine subfamilies. Of these, six include Neotropical species: Notodontinae, Dudusinae, Dioptinae, Pygaerinae, Heterocampinae and Nystaleinae.

Lobeza Herrich-Schäffer, 1854 is a poorly known genus with about 30 Neotropical species, occurring from Costa Rica to southeast Brazil. Besides the generic and species descriptions, Lobeza has been briefly treated in only two works. SpIтz (1931) described the morphology and behavior of the larva of Lobeza dentilinea Schaus, 1901, and Godfrey et al. (1989) studied the larval mouthparts of Lobeza suprema Schaus, 1894. Like many other genera of notodontids, Lobeza is not yet undoubtedly assigned to an available subfamilial name (GAEDe 1934). The genus is thought to be part of Heterocampinae as recognized in some well curated collections from the neotropics. However, with the lack of morphological or biological evidence this hypothesis remains controversial.

In the present paper, we provide detailed descriptions of the immature stages and imago of $L$. dentilinea, as well as of the male and female genitalia. We discuss the placement of the genus in Heterocampinae with evidence from immature and adult morphology. Based on laboratory rearing, male and female are confidently associated, and a redescription of the species is proposed based on both sexes (the original description includes only female characters).

\section{MATERIAL AND METHODS}

Last instar larvae of $L$. dentilinea were found near the Municipal Park of Pedroso, municipality of Santo André, state of São Paulo, southeastern Brazil (2345.3'S, 46 $\left.30.86^{\prime} \mathrm{W}\right)$, on Miconia sp. leaves (Melastomataceae). The larvae were transferred to the laboratory, where leaves of the host plant were offered ad libitum in a screen box $(30 \times 30 \times 30 \mathrm{~cm})$ under natural conditions of temperature and humidity. 
Three larvae were reared to adults, emerging two males and one female, which were caged for inducing pairing in captivity, but apparently they did not copulate because only infertile eggs were obtained in laboratory.

Eggs and pupae of $L$. dentilinea were photographed to document color patterns. Posteriorly, they were frozen for 24 hours. Larvae were also photographed and killed in hot water $\left(\right.$ ca. $80^{\circ} \mathrm{C}$ ), where they remained until the water cooled. The immatures were treated with Kahle's solution (PETERSon 1962) for 48 to 72 hours (larger specimens needed more time in the solution; see also DuArTe et al. 2005). Finally, all specimens were preserved in $70 \%$ ethanol. Immatures and adults were deposited in the Lepidoptera Collection of the Museu de Zoologia da Universidade de São Paulo, São Paulo, Brazil, except for a male, which will be deposited in the collection of Dr Vitor O. Becker, Camacan, Bahia, Brazil.

We followed standard procedures for preparation and study of female and male genitalia (Moraes \& Duarte 2009). The abdomen was carefully removed from each specimen and soaked in $10 \% \mathrm{KOH}$ for approximately 18 hours, being cleaned with a soft brush and opened by one side to remove the genitalia. Drawings were made with aid of camera lucida, and digitally edited with Adobe Illustrator ${ }^{\odot}$ CS3.

For description of the immature stages, we followed the terminology of Stehr (1987) and Miller (1991) for the larval chaetotaxy and general morphology; and Mosher (1916) for general morphology of the pupa. Terminology of the male and female genitalia follows KLots (1970), and COMMON (1979) for wing venation.

\section{RESULTS}

\section{Lobeza dentilinea Schaus, 1901}

Lobeza dentilinea Schaus, 1901: 320, 321. Holotype female, Brazil, São Paulo. Deposited at the National Museum of Natural History, Washington, DC (photograph examined).

\section{Egg (Fig. 1)}

Dome-shaped with smooth chorion. Light green at oviposition. Change in color pattern was not observed since the eggs were not fertilized. Average diameter $1.5 \mathrm{~mm}(\mathrm{n}=18)$.

\section{Last instar larva (Figs 2, 3 and 11-18)}

Coloration as described in SpITz (1931) (see also Figs 2 and 3). Head and body chaetotaxy as in Figs 12-14. Pore MGa, seta MG2, and secondary setae absent. Head rounded, narrower than thorax, slightly depressed at epicranial notch. Stemmata 1-6 nearly equal in size; however, in lateral view of head, stemma 3 distinctly smaller than others (Fig. 14). Stemma 5 ventral in position, near base of antennae separated from semicircle formed by stemmata $1,2,3,4$, and 6 . Antenna relatively shorter if compared to that of other notodontid species illustrated by Miller (1991: 121-122); medial segment about as long as wide. Labrum deeply notched. Anteclypeus somewhat protuberant in lateral view (Fig. 14). Mandibles symmetrical with smooth cutting edges. Maxillae as illustrated in Fig. 18, with fleshy stipital lobe dorsally (see also Grimes \& Neunzig 1986), minutely spiculated, rounded, and smaller than the rest of maxilla. Like other notodontids, mesal lobe with three sensilla trichodea (STI, STII, STIII) and two styloconica (LSS, MSS); a sixth sensillum (trichodeum), not yet named, positioned between LSS and MSS. Maxillary palpi about as long as wide. Labium as illustrated in Fig. 17, with palpus approximately equal in length to segment 1 of maxillary palpus; segment 1 of labial palpus entirely sclerotized. Spinneret approximately as long as labial palpi. Cervical gland apparently absent. Prothoracic shield strongly sclerotized, protuberances absent. Pretarsus of thoracic legs with four tarsal setae (Ts); Ts1 and Ts3 basal in position, and typically flattened and broad; Ts1 fork-shaped at tip, slightly longer than Ts3; Ts2 closer to claw base, slightly thicker than Ts4. Abdominal segments without protuberances. Prolegs equally developed on A3-A6, with three lateral setae each one. Proleg A10 with five lateral setae, slightly different from others, bearing almost same number of crochets (25 instead of 27) of A3-A6. Crochets in two transverse bands, homoideous uniordinal mesoseries. Paraprocts not elongate. Body length $6.5 \mathrm{~cm}(\mathrm{n}=1)$.

\section{Pupa (Figs 5, 6 and 19-21)}

Body cylindrical. Integument light brown, smooth, glabrous. Laterobasal angles of proboscis reaching eye sclerites; proboscis with anterior suture slightly curved and half the length of anterior wings; mesothoracic legs meeting at midline. Labial palpus sclerite absent. Antennae extending beyond mesothoracic legs. Prothoracic segment with two dorsal tubercules. Anterior margin of segments A5-A7 with dorsal shallow punctures. Segments A8-10 with rounded aspect, not tapering posteriorly; cremaster absent. Female pupa measuring $2.5 \mathrm{~cm}$ of length $(\mathrm{n}=1)$, male pupa measuring $1.5 \mathrm{~cm}$ of length $(\mathrm{n}=1)$.

\section{Imago (Figs 7-10 and 22-25)}

Head. Covered with long brown and white scales, the ones on vertex exceeding length of antennal scape. Eyes well developed. Ocelli present, light colored. Antennae bipectinate in both sexes. Male with many large sensila, female with only one at apex of comb. Antennal segments brown dorsally, with sparse white scales. Labial palpi not reaching dorsal margin of eyes. Proboscis shorter than length of head. Thorax. Predominantly brown dorsally, with white scales spread through whole thorax and orange scales on prothorax and mesothorax. Tarsi brown and white, other segments with the same pattern on external surface and orange on internal surface. Dorsal surface of anterior wing (female) covered with sparse brown and white scales, giving a dirty aspect; two longitudinal oblique and dentate lines of brown and orange scales, the proximal line from stem of vein $\mathrm{R}$ to inner margin, and the distal one from stem of veins $R_{4}+R_{5}$ to inner margin; posterior end of discocellular 


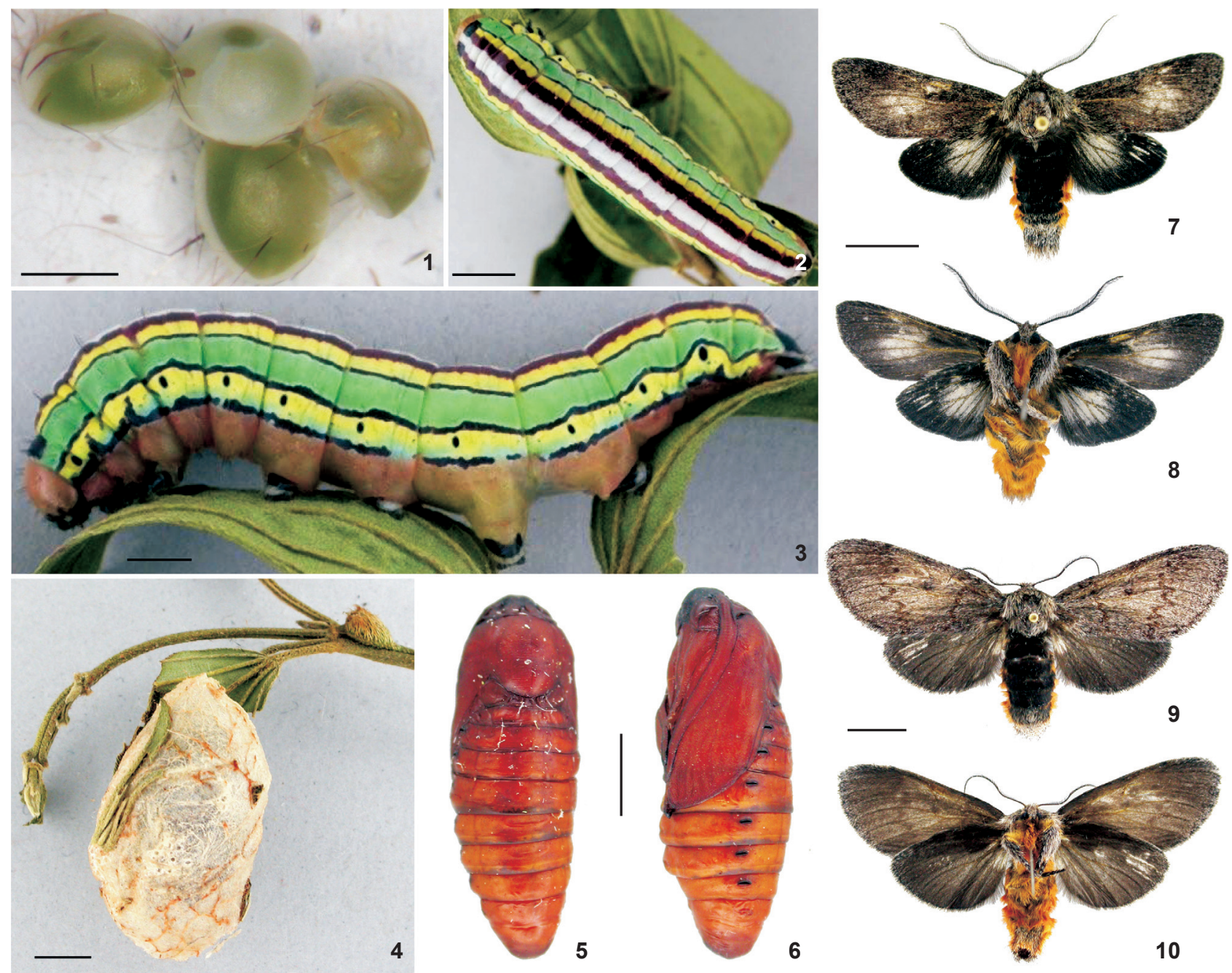

Figures 1-10. Immature stages and adults of L. dentilinea: (1) eggs; (2) last instar, dorsal view; (3) last instar, lateral view; (4) cocoon; (56) pupa in dorsal and lateral views; (7-8) male in dorsal and ventral views; (9-10) female in dorsal and ventral views. Scale bars: $1=15$ $\mathrm{mm}, 2=8 \mathrm{~mm}, 3=25 \mathrm{~mm}, 4-6=5 \mathrm{~mm} ; 7-10=10 \mathrm{~mm}$.

brown. Ventral surface brown with white scales on inner and outer margins, besides distal end of costal margin; proximal end of wings with bristled scales; fringe white. Venation trifid, $\mathrm{R}_{1}$ arising before discal cell; without accessory cell. Dorsal and ventral surfaces of posterior wing brown with distal portion of costal margin and fringe on outer margin white. Venation trifine. Anterior wing (male) as long as body length, with rounded apex; ground color of dorsal surface brown, with sparse white scales throughout wing and few orange scales medially; patch of white scales distal to discal cell. Ventral surface predominantly brown, with white scales medially and in costal and outer margins. Venation identical to that of female. Dorsal surface of posterior wing predominantly brown, with few white scales spread medially and on costal margin. Ventral sur- face entirely white; costal and outer margins with thin line of white scales, the rest of wing brown. Venation identical to that of female. Abdomen. Predominantly brown dorsally and orange in ventral view; segment I with small patch of white scales; segments II to VI, or II to VII, entirely brown dorsally, terminal segments covered with brown and white scales, giving a dirty aspect; all segments orange laterally; segments VII to VIII grayish ventrally; with cteniophores on male fourth sternite. Male and female eighth sternite similar in shape and sclerotization to other abdominal sternites. Female genitalia (Fig. 23). Lamellae antevaginalis and postvaginalis subequal in width and length. Antrum centralized. Ductus bursae short, sclerotized longitudinally, and about the same length of both lamellae. Corpus bursae lacking signa. Acessory bursae absent. Posterior 

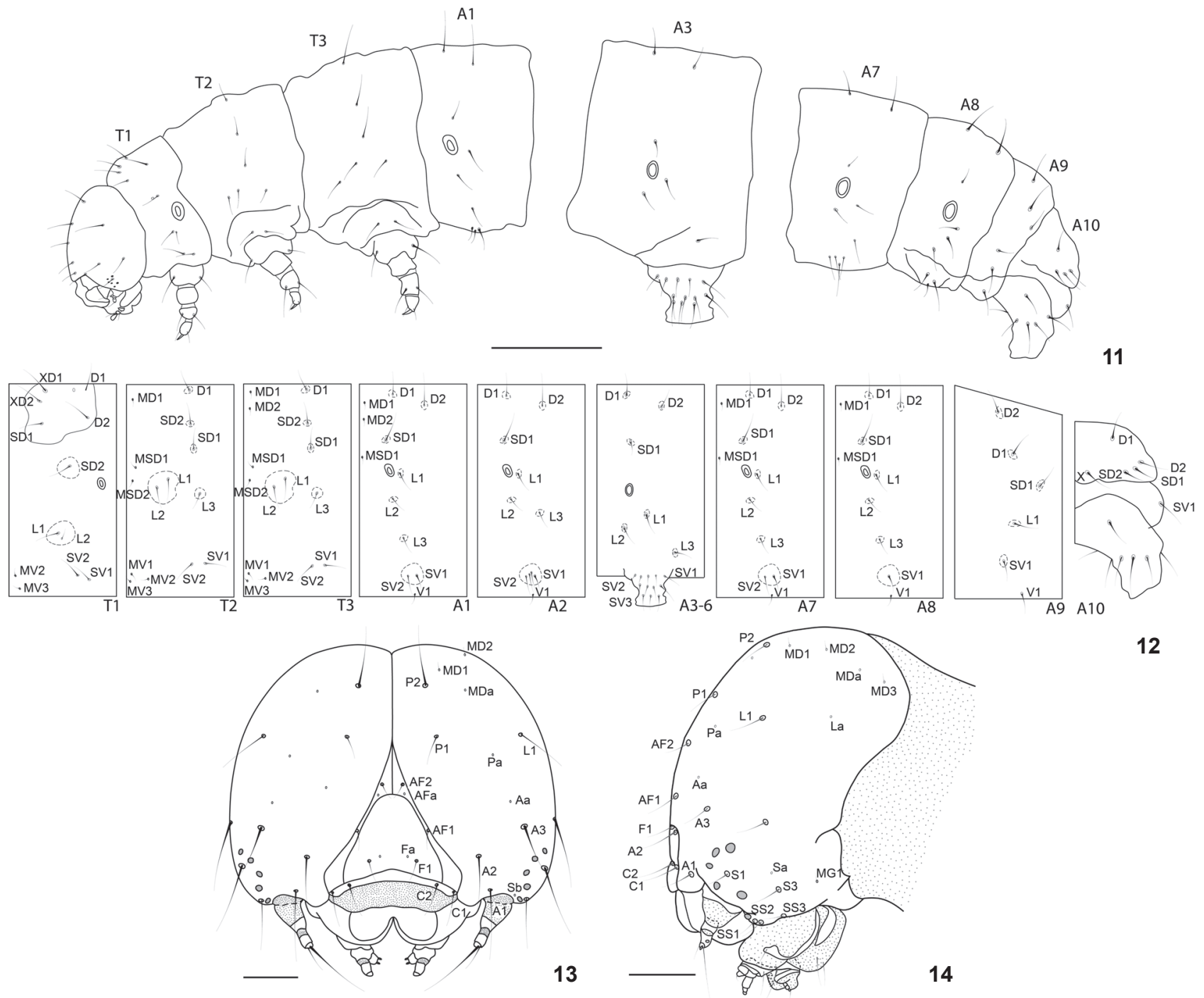

Figures 11-14. Last instar larva of L. dentilinea: (11) dorsolateral view; (12) body chaetotaxy; (13-14) head chaetotaxy in frontal (13) and lateral (14) views. (A) Anterior seta, (Aa) anterior pore, (AF) adfrontal seta, (C) clypeal seta, (D) dorsal seta, (F) frontal seta, (Fa) frontal pore, (L) lateral seta, (La) lateral pore, (MD) microdorsal seta, (MDa) microdorsal pore, (MG) microgenal seta, (Pa and Pb) parietal pores, (Sa and Sb) stemmatal pores, (SD) subdorsal seta, (SS) substemmatal seta, (SSa) substemmatal pore, (SV) subventral seta, (V) ventral seta, $(X)$ seta $X$ diagnostic for the notodontids, (XD) "XD" setal group. Pores and $V$ setae of thoracic segments and $A 3$ are not shown (they are located on the internal side of the leg). Proleg setae on A10 were not named due to the difficulty of recognizing homologies. Scale bar: $1 \mathrm{~mm}$.

apophyses approximately five times longer than anterior apophyses. Setae restricted to papillae anales and small area posterior to lamella postvaginalis. Male genitalia (Figs 24 and 25). Uncus broad, short and bifid. Tegumen scaled latero-ventrally. Gnathos pointed and well sclerotized, almost reaching posterior end of uncus. Valvae thin, sparsely scaled; cucullus fingerlike. Transtillae present. Juxta trapezoid with few setae above sclerotized area. Saccus not developed. Aedeagus straight and smooth; coecum long and straight. Vesica with cluster of spiniform cornuti on dorsal surface and transversal row ventrally oriented.

\section{Biology}

We collected larvae of $L$. dentilinea on leaves of Miconia sp. (Melastomataceae). Tibouchina pulchra (Cham.) Cogn. (Melastomataceae) has also been recorded as larval host plant 


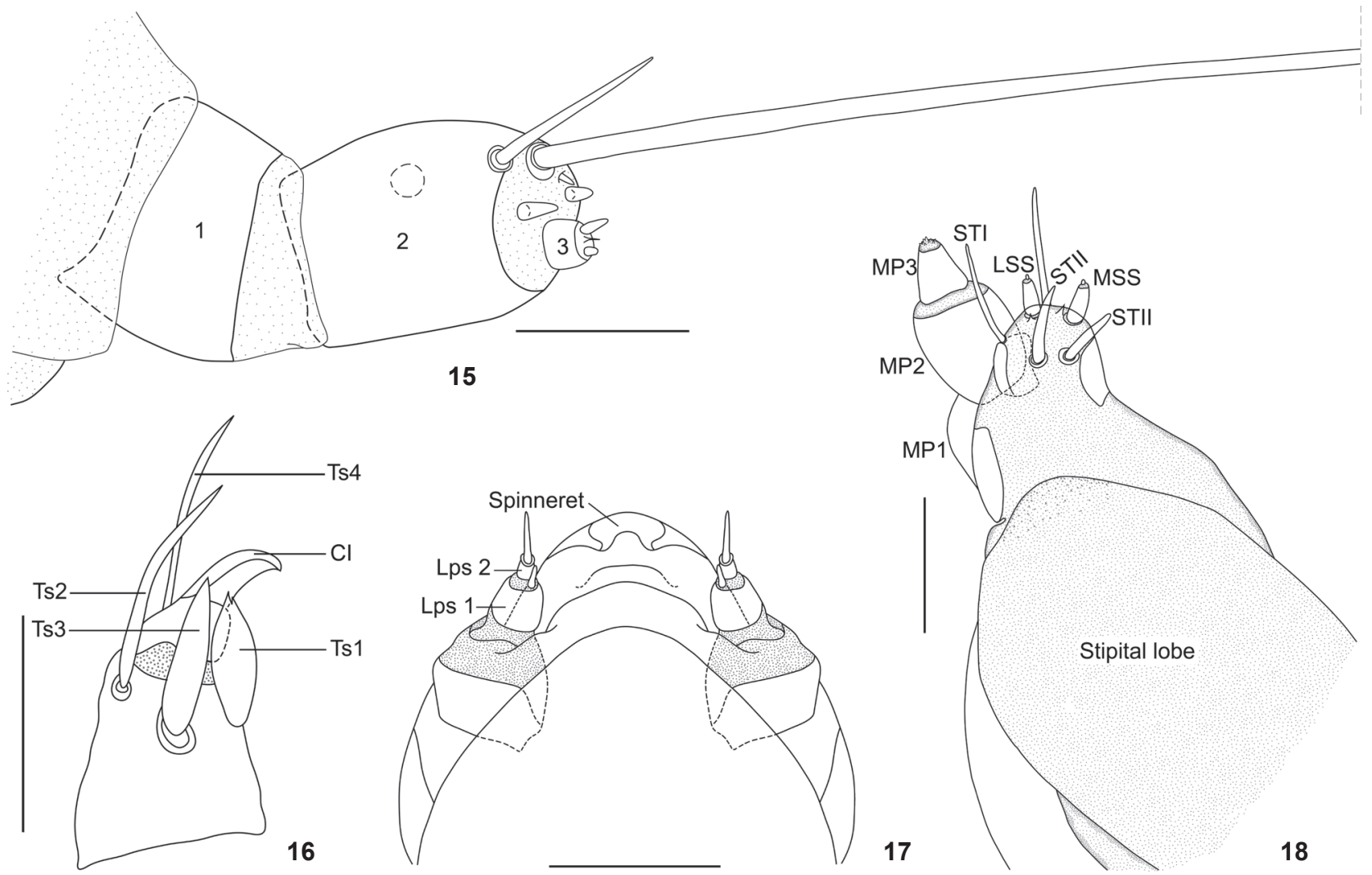

Figures 15-18. Last instar larva of L. dentilinea: (15) left antenna, lateral view; (16) Left pretarsus of mesothoracic leg, mesal view; (17) labium, dorsal view; (18) left maxilla, dorsoposterior view. (Cl) Claw, (Lps) labial palpus segment, (LSS) lateral styloconicum sensillum, (MP) segment of maxillary palpus, (MSS) medial styloconicum sensillum, (Sp) spinneret, (ST) sensillum trichodeum, (Ts) tarsal seta. Scale bar: $0.2 \mathrm{~mm}$.

for this moth (SPITz 1931). We observed approximately up to 40 larvae per plant, each plant with $1.5 \mathrm{~m}$ of height. The reduced number of reared specimens and the unfavorable laboratory conditions prevented us to report much about larval behavior. All larvae were collected in the penultimate instar, possibly the fourth instar considering that the number of five instars may be more widespread in Lepidoptera (see also DUARTE \& Robiss 2009). Although several larvae may be present on a single plant, they do not seem to be gregarious (at least in late instars). None of the larvae presented the usual position adopted by many notodontid larvae, with the last abdominal segments bended dorsally. The larvae eat the exuviae entirely after the ecdysis. Penultimate and last instars are morphologically very similar. Before pupation the larvae construct a dense cocoon formed of salivary secretions and some small pieces of leaves from the host plant. As described in Sitz (1931), the larvae of L. dentilinea generally pupate in the soil, but in the laboratory they were observed building cocoons on the bottom of the rearing cage attached to the host plant remnants. Female adults are larger than males (Figs 7-10).
Remarks. Brown \& Freitas (2000) illustrated a larva of $L$. dentilinea, but attributed it to an adult identified as Eudocima serpentifera (Walker, 1857) (Noctuidae: Calpinae). The known occurrence of L. dentilinea is restricted to the state of São Paulo, with records for the cities of São Paulo and Campos do Jordão, from sea level to an altitude of $700 \mathrm{~m}$. Notes on the larval behavior are found in Sirtz (1931).

\section{DISCUSSION}

Although the monophyly of most subfamilies of Notodontidae has yet to be firmly established, Miller (1991, 1992a) did provide the framework for further contributions. Even though his concept of some subfamilies differs significantly from previous authors (e.g. Gaede 1934), Miller's subgroups of Notodontidae were tentatively delimitated on the basis of informative characters of immature stages and adults. Our morphological evidence suggests that Lobeza belongs to Notodontinae, and not to Heterocampinae as previously hypothesized (see introduction). The characters supporting the placement in 


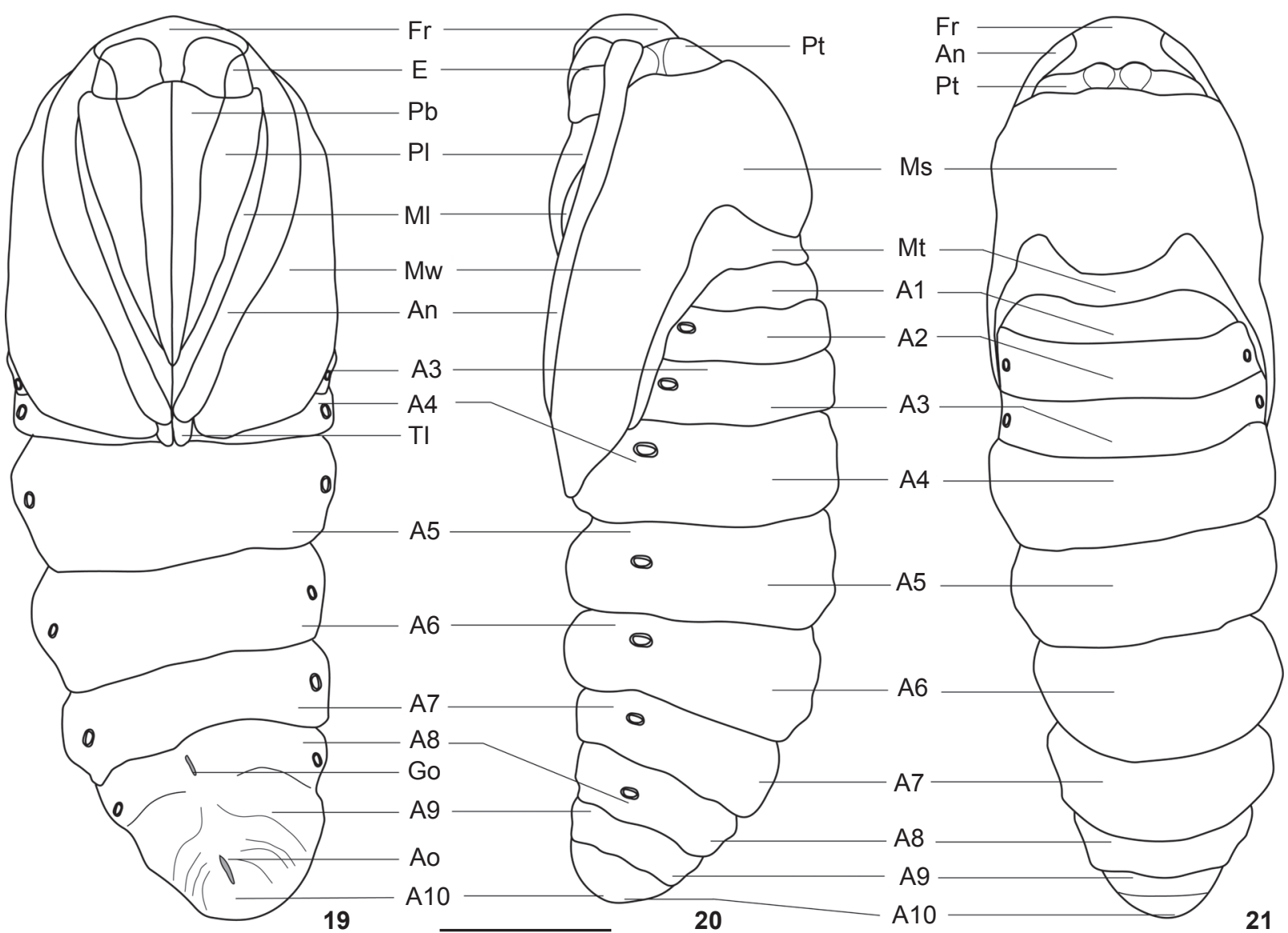

Figures 19-21. Pupa of L. dentilinea: (19) ventral view; (20) lateral view; (21) dorsal view. (A) Abdominal segment, (An) antenna, (Ao) anal opening, (E) eye, (Fr) frons, (Go) genital opening, (Ml) mesothoracic leg, (Ms) mesothorax, (Mt) metathorax, (Mw) mesothoracic wing, $(\mathrm{Pb})$ proboscis, $(\mathrm{Pl})$ prothoracic leg, $(\mathrm{Pt})$ prothorax, $(\mathrm{Tl})$ metathoracic leg. Scale bar: $5 \mathrm{~mm}$.
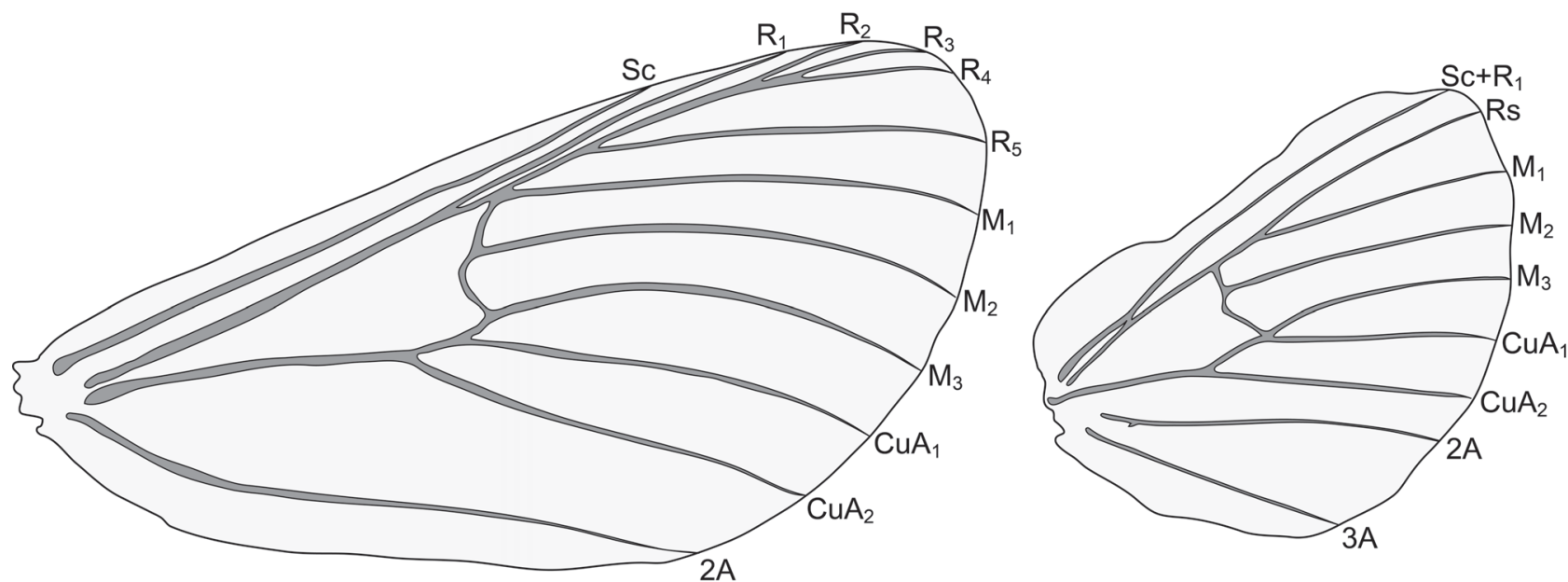

Figure 22. Fore and hind wings of $L$. dentilinea. (A) Anal vein, (CuA) cubital vein, $(M)$ medial vein, (R) radial vein, (Rs) radial sector, (Sc) subcostal vein. Scale bar: $10 \mathrm{~mm}$. 


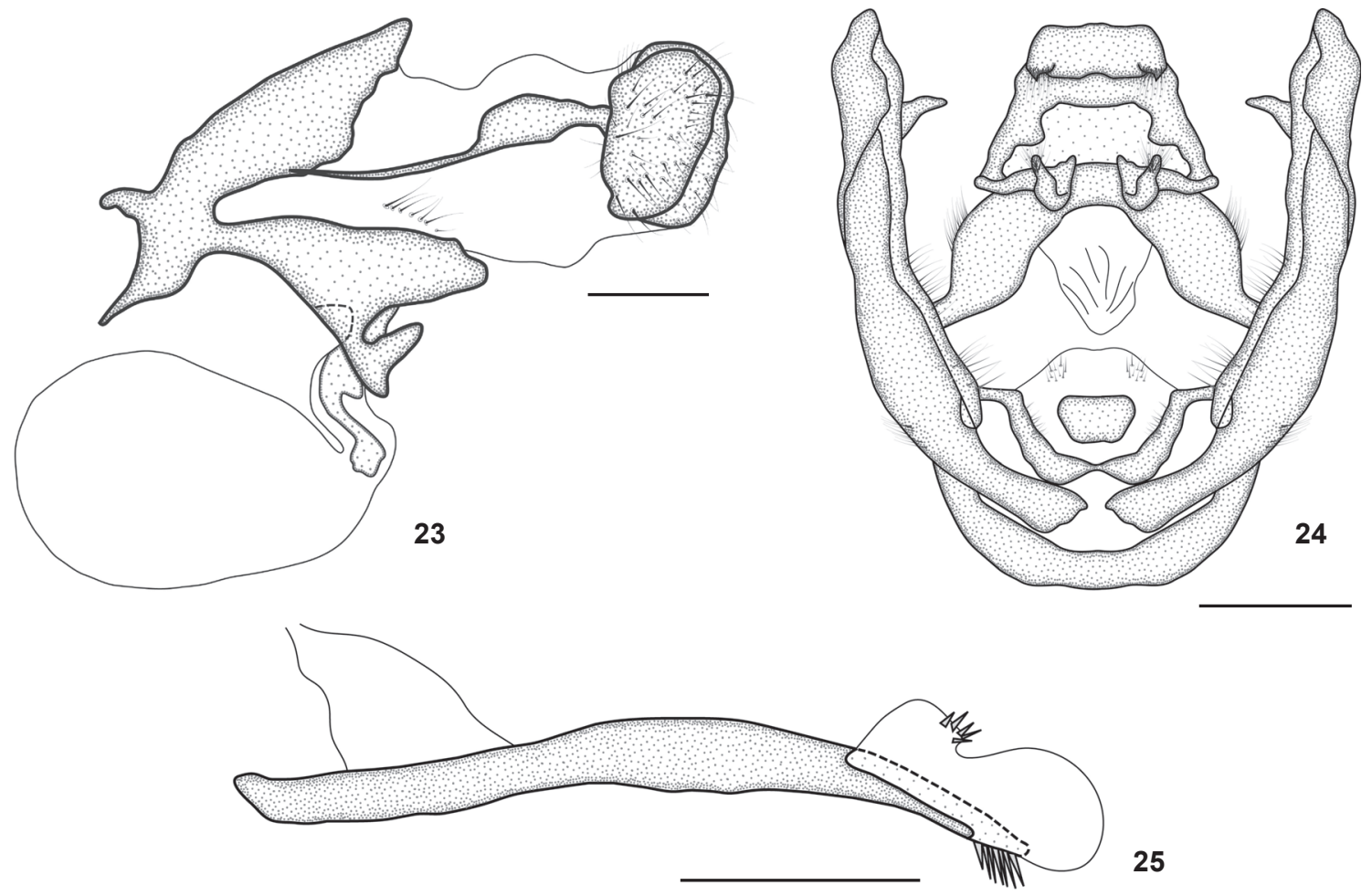

Figures 23-25. Female and male genitalia of L. dentilinea: (23) female, lateral view; (24-25) male: (24) genital capsule, posterior view; (25) aedeagus, lateral view. Scale bar: $1 \mathrm{~mm}$.

Notodontinae are the following (see also MiLler 1991): last abdominal segments of pupae broadly rounded, proboscis smaller than the length of the head, epiphysis with more than half the length of tibia, tarsal claws simple, and labial palpi short. Differing from other notodontines (Miller 1991), a fourth L seta on segments A3-A6 is lacking in L. dentilinea.

MiLLER (1991) divided the Notodontinae into Notodontini and Dicranurini. Lobeza is probably better placed in the latter because of the male flat epiphysis (about as long as tibia), the absence of a proximal pair of spurs and absence of forewing accessory cells. Lobeza dentilinea does not have all characters suggested as synapomorphic for Dicranurini; however, given the limited number of species available when Miller (1991) developed his work, it is expected that some of the listed characters do not represent synapomorphies of the entire group.

Concerning larval food plant preference in Dicranurini, most of the species feed on Salicaceae, with some reports also mentioning the use of Sapindaceae, Rosaceae and Fagaceae (Miller 1991). Larvae of L. dentilinea are for the first time found feeding on the genus Miconia Ruiz \& Pav., and it is the second record of a host plant belonging to Melastomataceae. Miller (1991) did not mention this plant family for the Notodontinae, possibly due to the unexpected placement of Lobeza in the subfamily.

\section{ACKNOWLEDGEMENTS}

We thank Vitor O. Becker, who identified the species, Don Harvey (USNM) for the holotype picture, and two anonymous reviewers for useful comments on the manuscript. For recent financial support MD thanks FAPESP (as part of the project "Systematics, Bionomy, and Evolution of Neotropical Lepidoptera"; processes 2002/13898-0 and 2003/13985-3), CNPq (as part of the project "National Network for Research and Conservation of Lepidoptera/ SISBIOTA-Brasil"; process 563332/2010-7), and Pró-Reitoria de Pesquisa da Universidade de São Paulo/USP/Projeto 1. LRP and ROS have also been supported by FAPESP (2009/ 11159-5 and 2011/03409-1, respectively).

\section{LITERATURE CITED}

Common, I.F.B. 1979. Lepidoptera, p. 765-866. In: CSIRO. The insects of Australia. Carlton, Melbourne University Press, $\mathrm{XIV+1029p.}$

Brown Jr, K.S. \& A.V.L. Freitas. 2000. Diversidade de Lepidoptera em Santa Teresa, Espírito Santo. Boletim do Museu Biológico Mello Leitão (Nova Série) 11/12: 71-118.

DuARTE, M.; R.K. Robbins \& O.H.H. MielKe. 2005. Immature stages of Calycopis caulonia (Hewitson, 1877) (Lepidoptera, Lycae- 
nidae, Theclinae, Eumaeini), with notes on rearing detritivorous hairstreaks on artificial diet. Zootaxa 1063: 1-31.

DuARTE, M. \& R.K. Robbins. 2009. Immature stages of Calycopis bellera (Hewitson) and C. janeirica (Felder) (Lepidoptera, Lycaenidae, Theclinae, Eumaeini): taxonomic significance and new evidence for detritivory. Zootaxa 2325: 39-61.

Dyar, H.G. 1897. A generic revision of the Ptilodontidae and Melalophidae. Transactions of the American Entomological Society $24: 1-20$.

GAEDE, M. 1934. Notodontidae. In: E. STRAND (Ed.). Lepidopterorum Catalogus. Berlin, W. Junk Publishers, part 59, 351p.

Godfrey, G.L.; J.S. Miller \& D.J. Carter. 1989. Two mouthpart modifications in larval Notodontidae (Lepidoptera): their taxonomic distributions and putative functions. Journal of the New York Entomological Society 97 (4): 455-470.

Grimes, L.R. \& H.H. NeunZIG. 1986. Morphological survey of the maxillae in last-stage larvae of the suborder Ditrysia (Lepidoptera): mesal lobes (Laciniogaleae). Annals of the Entomological Society of America 79 (3): 510-526.

KLots, A. 1970. Lepidoptera, p. 115-130. In: S.L. Tuxen (Ed.). Taxonomist's glossary of genitalia in insects. Copenhagen, Munksgaard, 359p.

Miller, J.S. 1991. Cladistics and classification of the Notodontidae (Lepidoptera: Noctuoidea) based on larval and adult morphology. Bulletin of the American Museum of Natural History 204: 1-230.

Submitted: 06.XII.2010; Accepted: 03.VII.2011. Editorial responsibility: Gabriel L.F. Mejdalani
MiLler, J.S. 1992a. Pupal morphology and the subfamily classification of the Notodontidae (Lepidoptera, Noctuoidea). Journal of the New York Entomological Society 100 (2): 228-256.

Miller, J.S. 1992b. Host-plant associations among prominent moths. Bioscience 42 (1): 50-57.

Moraes, S. S. \& M. Duarte. 2009. Morfologia externa comparada das três espécies do complexo Telchin licus (Drury) (Lepidoptera, Castniidae) com uma sinonímia. Revista Brasileira de Entomologia 53 (2): 245-265.

Mosher, E. 1916. A classification of the Lepidoptera based on characters of the pupa. Bulletin of the Illinois State Laboratory of Natural History 12: 14-159.

Peterson, A. 1962. Larvae of insects. An introduction to Nearctic species. Part I Lepidoptera and plant infesting Hymenoptera. Michigan, Edwards Brothers Inc. Ann Arbor, 315p.

Schaus, W. 1901. A revision of the American Notodontidae. Transactions of the Royal Entomological Society of London 49 (3): 257-344.

SeITZ, A. 1932. Notodontidae, general topics, p. 901-905. In: A. SEITZ (Ed.). Macrolepidoptera of the World. Stuttgart, Alfred Kernen, vol. 6.

SitTz, R. 1931. Espécies novas de macrolepidópteros brasileiros e suas biologias. Revista do Museu Paulista 17 (1): 459-482.

STEHR, F.W. 1987. Order Lepidoptera, p. 288-305. In: F.W. STEHR (Ed.). Immature insects. Dubuque, Kendall/Hunt, vol. 1, $\mathrm{XII}+754 \mathrm{p}$. 